\title{
Conditions for Success in a Community Based Conservation Initiative: An Analysis of Triggering Moments and Catalytic Elements in Nuha
}

\author{
Nurhady Sirimorok ${ }^{1, *}$ and Eko Rusdianto ${ }^{1}$ \\ 1 Peasant School Network of PAYO-PAYO. Maros, South Sulawesi, Indonesia.karnobatiran@payopayo.or.id \\ * Corresponding author: nurhadys@gmail.com
}

\begin{abstract}
What accounts for a successful community-based conservation (CBC) initiative? A bulk of studies has answered the question by identifying the principles as well as underlying relations that make up successful cases. However, rarely do they extend to examine the basic elements (or ingredients) that contribute to a successful case. Using the analytic framing of triggering moments and catalytic elements, this study describes the key factors that contributed to ongoing successes in achieving the outputs and goals of CBC. A recent CBC project in the Lake Malili Complex of South Sulawesi is examined as a case study to test the framework. The CBC initiative was carried out by a local NGO and university. The case village (Nuha) is chosen for its ability to continue implementing programmatic objectives according to project reports. Indepth interviews, a close review of grey literature about the project, as well as field observations in Nuha and surrounding villages provide the data that forms the basis of the analysis about the factors contributing to Nuha success. Findings show that the framework of triggering moments and catalytic elements can help to show the key factors of crises and windows of opportunity that contribute strongly to stimulating community responses to a CBC initiative. Furthermore, although not all catalytic elements were present, certain identified factors - participation, commitment of key actors, funding, capacity building, partnership with supportive organizations and governments, and leadership - were strong enough to stimulate effective implementation of the CBC initiative. Nevertheless, the analytic framework of triggering moments and catalytic elements is less capable of providing the context for why the catalytic elements were present prior to the introduction of the $\mathrm{CBC}$ initiative.
\end{abstract}

Keywords: Community-Based Conservation ( $\mathrm{CBC}$ ); triggering moments; catalytic elements; political ecology

\section{Introduction}

Community-based conservation ( $\mathrm{CBC}$ ) initiatives has been advocated and practiced for its inclusiveness in terms of human-and-nature relations, bottom-up approach, as well as recognition of multilevel and complex systems (Berkes, 2004; Sandbrook, 2015; Pearson, 2016). The existing literature on commons tends to focus on different principles of how rules are set up to jointly manage resources (Ostrom, 1990; Lemos and Agrawal, 2006; Cox et. al., 2010; Saunders, 2014; Baggio et. al., 2016). Other frameworks have examined power relations as it relates to access and exclusion (Ribot and Peluso, 2003; Hall et al., 2011). However, the bulk of this literature is focused on the pre-existing and historically situated aspects of governance. Rarely do these frameworks extend into the assessment of programmatic aspects of $C B C$ initiatives. More specifically, the key elements (or "ingredients") mixed by those principles and relations to form a successful CBC initiative forms the focus of this paper. Seixas and Davy (2007) sought to examine this particular aspect through community based conservation (CBC) initiatives and their programmatic interventions across seven selected cases of Equator Prize finalists and shortlisted nominees in 2002 and 2004. Rather than engaging in a more macro analysis of so many cases, this paper extends the Seixas and Davy framework (2008) by devoting our attention to the analytical potential of more closely examining the ingredients of success at a specific site.

Seixas and Davy (2007) identify factors that initiate and maintain CBC initiatives from various cases, which they term 'Triggering Moments' and 'Catalytic Elements.' Triggering moments are motives or events that initiate the key actors in the community to self-organize for CBC initiatives. 
They may be real or predicted crises, windows of opportunity, and following orders from outside parties. Catalytic elements are the factors that propel and maintain self-organizing around CBC initiatives. They can be participation commitment of key actors, funding, capacity building, partnership with supportive organizations and governments, leadership, and economic incentives. In this paper, we examine the factors that make up the success of a CBC in Nuha by applying the framework developed by Seixas and Davy (2007), while identifying shortcoming of the framework.

\subsection{A close examination of a successful site in Nuha}

In 2016-2018, a local NGO (i.e. Perkumpulan Wallacea) and university (Universitas Andi Djemma [hereafter Unanda]) was supported by Burung Indonesia to work on CBC initiatives with four villages in the Lake Malili Complex, Luwu Timur Regency of South Sulawesi. The project objectives of each organization were closely related. While Perkumpulan Wallacea was working towards sustainable farming and land use, Unanda aimed at participatory protection and conservation of population and habitat of endemic trees: Rode (Vatica flavovirens/celebica), Dama'dere (Vatica rassak), and Mata Kucing (Hopea celebica). Perkumpulan Wallacea conducted participatory mapping, participatory land use planning, and developed alternative sustainable livelihoods. Meanwhile Unanda carried out awareness raising for endangered endemic tree species, as well as establishing agroforestry groups within each village which then practiced nursery development and planted endemic trees as part of the agroforestry program. ${ }^{1}$

The village of Nuha was able to continue implementing programmatic objectives beyond the projects. In Nuha the two organizations succeeded in carrying out all project activities and relatively good qualities. According to the project report by Unanda, the Nuha agroforestry group is able to maintain their activities to produce seedlings, maintain the nursery, and plant trees, as well as post plantation care of endangered endemic species. Nuha is also reported by the Perkumpulan Wallacea as having a successful and substantive involvement in participatory mapping and participatory land use planning. Villagers actively participated throughout the participatory mapping, analysis, and the formulation of a participatory land use plan, as well as the public consultation of the resulting land use plan. The plan has been adopted in a village regulation and became a reference for village development planning. Finally, as land conversion associated with a pepper came to the regency in 2012 , it did not encroach on the village protected forest areas, although today most families in Nuha are planting pepper as their main income source. ${ }^{2}$ Many other villages surrounding the Lake Malili Complex on the other hand, experienced widespread conversion of protected areas into extensive pepper groves. $^{3}$

The question for this research is therefore: why has Nuha succeeded in protecting its forests? Concepts developed by Seixas and Davy (2007) are thus applied to frame the overall factors associated with stimulating and maintaining community self-organization for successful CBC. By testing the framework to a single case the paper aims to contribute both practical and theoretical insights on how to achieve a successful CBC initiative.

\footnotetext{
${ }^{1}$ These projects are part of the Burung Indonesia program from the Wallacea Region.

${ }^{2}$ The pepper is striving in Nuha because of the suitable weather and soil and water $\mathrm{pH}$, as well as nursery seedling skills that the local acquired from multiple trainings. The rate of seedling survival rate in Nuha is one of the highest in the area, amounting to around 80 percent. Indeed, according to one of the Nuha village statistic, Nuha is claimed by Provincial Nursery Agency (Balai Benih Propinsi) as one of the best pepper nursery area in Indonesia.

${ }^{3}$ Report and minutes of meeting in villages produced by NGOs working in the area reveal stories in other villages around Malili Lake Complex. The villagers complained how outsiders can easily come to convert forest into pepper groves in their village while the villagers are closely watched from doing such activity.
} 


\section{Methodology}

Recent debate on conservation points to more inclusive conservation considerations, whereby conservation is not only done to preserve nature irrespective of humans (for its intrinsic value), but also for different functions that nature brings to humans, directly (as a utilitarian value) or indirectly (non-use value). Conservation can therefore be approached with multiple and nuanced framings that involve complex relations between humans and biodiversity (Sandbrook, 2015; Pearson, 2016). This stance sits comfortably with the $\mathrm{CBC}$ perspective, which recognizes that humans are part of nature, which forms complex governance dynamics that unfold across multiple scales. "If conservation issues are complex-systems problems, they have to be addressed simultaneously at various scales" (Berkes 2004: 625). Thus, local communities and their surroundings are a legitimate part of the conservation.

The notion of 'putting humans back into nature' instead of 'nature for itself' (Pearson, 2016) allows for rectification of deficiency of old conservation model that was expulsive (to invent "pristine nature"), expert-driven, and top-down. Altogether, they form the basis for recognition of the community as part of the solution in conservation and the $C B C$ as a conservation approach to flourish (Adams, 2003; Berkes, 2004; Horwich and Lyon, 2007).

Partly responding to this shift in conservation thinking, Berkes (2004) argues that "asking whether the community-based conservation works or not is the wrong question. Sometimes it does, sometimes it does not. Rather, it is more important to learn about the conditions under which it does or does not work." (p. 624) Presenting their extensive works in developing countries, Horwich and Lyon (2007) contends that the CBC does work, and it works especially when it operates in decentralized governance systems at a small-scale. Working at a regional level, the CBCs have a better chance of beginning with individual communities, and the small-scale CBC is adaptable and transferable to regional and national levels. Taking from both stances the present case study focuses on a CBC effort in a single village, Nuha, and examines the conditions under which this particular small-scale effort can work. This case study makes use of a synthesis developed by Seixas and Davy (2007) in terms of trigger events and catalytic elements.

They identify at least four motives or trigger events that stimulate a community to begin selforganizing for $\mathrm{CBC}$ projects as:

- First, a response to identified or felt crises. It might be a fight for the rights and cultural revitalization, trying to solve conflicts, or responding to environmental degradation, threats or disasters.

- Second, preparation for predicted crisis, which is a vision of possible changes to improve the social-ecological system (i.e., of potential project outcomes) is the first step to plan a successful initiative.

- Third, following the order from an outside agenda, this may comprise of a plan to implement conservation and/or development agendas.

- Fourth, to take advantage of a new window of opportunity, an initiative may include a search for an alternative livelihood or a new market opportunity.

In terms of catalytic elements, Seixas and Davy (2007) found six distinct factors that support and maintain the successful CBC projects. They are: "(1) involvement and commitment of key players (including communities), (2) funding, (3) strong leadership, (4) capacity building, (5) partnership with supportive organizations and government, and (6) economic incentives (including alternative livelihood options)" (p. 109). They concluded with two reminders: first, the existence of these six elements alone does not guarantee the success of a project as creativity in using these elements is also important. Second, not all elements are used in all projects and other different elements are used in some of the projects. But some of these six elements often need to come together, and that one or two elements are not sufficient to ensure success. 


\subsection{Data Collection}

We gathered data from systematic reading of grey literature produced during the projects by Wallacea and Unanda, including maps, meeting minutes, project reports, and other documents. We conducted purposive and in-depth interviews with more than 20 key informants, including representatives of government agencies, Perkumpulan Wallacea, Unanda, and community members. We conducted observation in Nuha and participated in one of the Forum meetings in the regency. The fieldwork was carried out in March-April 2019 over two visits. In addition, one of the authors had a longstanding engagement with the local issues, having lived in Sorowako for more than two years as a journalist and is familiar with local contacts and has significant knowledge about the social and political context of the regency. This familiarity helped us to locate the relevant informants, eased rapport with local villagers, and provided alternative knowledge from the broader notions of success about the site.

The grey literature provided us with preliminary data (Rahayu et al., 2019) with which we decided to select Nuha as the case study. The literature shows that Nuha had been successful during the project, providing us a suitable case to test the framework and identify the factors underpinning Nuha's achievements, as well as to inquire deeper to identify the conditions for success in a CBC initiative. Interviews with representatives from both Perkempulan Wallacea and Unanda provided confirmation of the Nuha achievements and offered more nuanced information on the processes during the projects, their inputs, and insights on villager reactions towards the inputs. Observations and interviews in Nuha informed us more on the processes and achievements during the projects from local perspectives, as well as providing additional information on the triggering moments and other aspects of village-based contexts. In this way we were able to triangulate the information gathered from both grey literatures and interviews outside the village.

Data was analyzed following the framework developed by Seixas and Davy's (2007), by first identifying and describing the triggering moments that strongly stimulate the CBC project in Nuha. Comparing the different types of data from each source helped us to construct descriptive narratives on the triggering moments. We then identified parts of the data that fit into each of the catalytic elements. Based on sorted the data, we examined the extent to which each of the elements supported the success of the initiative in Nuha. Laying out the catalytic elements on the extent to which each of them contributed to the $\mathrm{CBC}$ efforts in Nuha, allowed us to see beyond the immediate factors around the $\mathrm{CBC}$ project into the historical and more nuanced local perspectives, identifying strengths and shortcomings of the framework.

\section{Study context}

\subsection{Dual Economies in Nuha}

The Village of Nuha is located at the north bank of Matano Lake, one of three large lakes within the Lake Malili Complex, East Luwu Regency, in the Province of South Sulawesi. The Complex is situated at the northeastern tip of the province, around 600 kilometres from the provincial capital, bordering Central and Southeast Sulawesi Province. Nuha is also located on the border with Central Sulawesi Province. ${ }^{4}$ To the south of Lake Matano and Mahalona are mine concessions, the plant site, offices and the housing complex of a large nickel mining company (PT Vale) employees, as well as the densely populated town of 'Sorowako' (name for the area under administrative jurisdiction of Sorowako, Nikkel, and Magani Villages). To the south of Lake Matano, the residents almost

\footnotetext{
${ }^{4}$ The Lake Complex comprises of three large lakes: Matano (16.408 ha), Mahalona (2.440 ha), and Towuti (56.108 ha), each with different elevation that enable the highest one, Matano ( $382 \mathrm{~m}$ above sea level) to supply water to the lower ones, Mahalona (310 masl), Towuti (280 masl). The water from Towuti then flows to a large River, Larona, that flows into the Gulf of Bone. Alongside the large lakes are two small lakes, Masapi and Lantoa.
} 
exclusively depend on PT Vale. Besides working for the company, they also work for hundreds of contractors competing to gain contracts from PT Vale and the diverse services supporting them.

The Nuha cultivators have been practicing dual economies similar to elsewhere across Southeast Asia, where smallholders produce rice for subsistence and other commodities for the market (Dove, 2012: 14). Until the 1980s, Nuha cultivators practiced swidden rice cultivation, which were manually weeded without applying chemical fertilizer. ${ }^{5}$ Rice cultivation underwent transformation in the mid-1990s, when gaharu (agarwood) collection reached its peak in Nuha. Opening road access brought tractors and chemical inputs to the area, and agricultural practices began to follow modernized wet rice cultivation. ${ }^{6}$ Today the main crops in Nuha are rice and pepper. The people of Nuha cultivate rice for subsistence, and the small amount of rice surplus is usually sold within the village or to relatives who work in Soroako.

Through the 1990s, Nuha produced and sold damar resin, rattan, gaharu and vegetables. ${ }^{7}$ Since around 1991, Nuha became one of the main sources of kalapi timber ${ }^{8}$ but which ended in the early 2000 s as it became an illegal activity after the establishment of protected forests which covers the most of the village. Cows in Nuha are free to roam in the savanna or forested areas within the village. Besides commodities, forests in Nuha host endangered and/or endemic species: anoas are occasionally seen by the villagers in the forest, endemic trees such as damadere grow in Nuha, and used as fencing for croplands because they last long against the seasons-and for the same reason have lately been used for the growing poles for pepper vines.

Many of the Nuha children leave the village to continue their school after primary school, since Nuha does not have a middle school. They go to Soroako or other nearby towns and live with relatives. Some of them will return after completing their undergraduate degrees in a regional capital and find themselves unemployed or operating boats to bring passengers to cross Lake Matano, between Nuha and Soroako Town.

Further transformation in the economic system may have come to Nuha since the early 2010s, when the pepper boom began. An informant in Nuha expressed that today rice is relegated to a secondary crop, since all Nuha smallholders are planting pepper. Rice cultivation depends on the remaining labor available after priorities for the main crop. Families with limited labor are using their physical power only to plant pepper. Alternatively, they share-crop their rice fields to other farmers so that "the rice fields will not turn into a savanna', and become a dead rice field." Many potential youth farmers now reside in Soroako, working or continuing their education. The swidden rice fields no longer exist, and the area of wet rice fields is decreasing since many of the rice fields are being converted into pepper fields. Today, all the cultivators who own rice fields also have pepper groves, but not all those who have pepper own rice fields. The financial attractiveness of pepper seems to pose a threat to the longstanding dual economy that was the norm for a very long time. $^{9}$

\footnotetext{
${ }^{5}$ Wet rice planted in January to February, and most of the time the second planting season come in April, depending on the availability of water (the rice fields are rainfed).

${ }^{6}$ Swidden rice planted in January, right before dry season and similar to wet rice, and harvested in July. January is one of the busiest months since local people have to plant rice and pepper. There were six kinds of local swidden rice seeds they used to plant regularly, which span from 3 to 6 months before harvest. Among others, they are: beu, oasi, ompuda, pulu lauro. They store the harvest in specially built barns to avoid rats. Rice seeds used by the Nuha cultivators are those developed by seed industry such as sentana, cinta nur, Banda, and IR 42

${ }^{7}$ The damar was not cultivated but they have ownership system for the damar trees: the first one who tapped the damar tree will own the tree and will be able to pass the trees down to children as inheritance.

${ }^{8}$ They selected older kalapi, those that old enough and able to produce around 1,5 cubic meters, and cut them with chainsaw. The timbers then pulled with buffalo to the lake or roadside for further transportation to nearby town where they are selected based on quality ("the older the better") before transaction.

${ }^{9}$ Some households plant corn (between the lines of pepper), or cassava, but only for own consumption and with little regularity. Some families also plant vegetables (pandole, chili, tomatoes, and different cultigens) between the pepper, as well as coffee and durians, also for own consumption.
} 


\subsection{Community-Based Conservation in Nuha}

The $\mathrm{CBC}$ projects in Nuha are part of a broader program that covers the Wallacea region (Timor Leste, Lesser Sunda, Sulawesi and Maluku). The Critical Ecology Partnership Fund, working with Burung Indonesia as the Regional Implementation Team, selected local CSO grantees to run projects with the communities. The two local organizations working in Nuha, Perkumpulan Wallacea and Unanda, are both based in Palopo. ${ }^{10}$ Both worked roughly during the same period, between early 2016 through the end of 2018, in several villages in two sub-regencies: Nuha and Towuti, the two sub-regencies directly surrounding the banks of the five lakes within the Malili Lake Complex (Sirimorok and Rusdianto, 2020).

Unanda began with research on threatened endemic trees: Rode (Vatica flavovirens/celebica), Dama'dere (Vatica rassak), and Mata Kucing (Hopea celebica) and their habitats, then proceeded to introduce and create awareness about endemic trees, and trained community groups to rehabilitate the trees. Meanwhile, Perkumpulan Wallacea organized communities to work around sustainable land use and participatory bottom-up decision making processes. Their main agenda was participatory mapping and land use planning (PLUP), as well as organic farming initiatives such as agroforestry and trigona bees breeding. The PLUP initiative included mapping traditionally protected areas which were also the habitat of the endemic trees. During this processes, Perkumpulan Wallacea introduced a range of new skills and knowledge to the community members, from approaches to making organic fertilizer, mapping using Global Positioning System (GPS) tracker, and drafting land use plans and village regulations based on the results of participatory mapping. Furthermore, this engagement also helped to establish agroforestry groups (Kelompok Tani Hutan) that became the local institutions managing nurseries of the endemic trees trained by Unanda.

In the later stages of the project, they supported advocacy through multi-stakeholder meetings and trainings, including workshops with the sub-regency and regency level government, but mostly limited to the sub-regency government and regency offices directly related to their advocacy (such as forestry, fishery, and the environment offices). These initial activities provided potential stakeholders that later created a forum in the regency level: Forum Pemerhati Kompleks Danau Malili (Forum for the Lake Malili Complex, henceforth the Forum). Importantly, the implementation of the previous activities also provided the justification for establishing the Forum and guiding its activities. Among the strongest motives for the villagers to join the Forum were to advocate for their land rights, as many of their agricultural lands and settlements areas overlapped with formal jurisdictions (such as protected areas or land concessions).

\section{Results}

\subsection{Triggering Moments: Forest enclosure and a pepper boom}

Crises, both felt and predicted, form the significant motivation that contributed to the positive responses toward the projects in Nuha. These crises are frequently mentioned by villagers when they talk about the context of the project, or "the problems" that the project could help to solve. These crises are related to closure of villager croplands and the stoppage of basic public infrastructures as the village became part of the protected forest, as well as the recent pepper boom in the region that invited poachers from outside to enter the protected areas. These current and envisioned crises created a strong impetus for self-organizing on conservation and livelihoods improvement.

\footnotetext{
10 Palopo is a former capital city of Luwu Regency before it was divided into three regencies and one municipality: Regency of Luwu, North Luwu, and East Luwu, and Municipality of Palopo.
} 
Villager stories reveal how Nuha have experienced a longstanding problem related to the establishment of the protected forest. The establishment process began around 2001, when a mapping team came from the provincial office. They hired several villagers who were excluded from any decision making processes, especially related to their suggestions concerning the borders of the future protected forest, which were denied during the mapping. One community leader who was involved in the mapping recalled how the team "couldn't care less" ("tidak mau pusing") and were "too lazy to walk far into the forest" that they took the easier paths at the expense of villagers croplands. In one instance they cut a villager's clove tree to post a boundary marker within the villager's groves, and even intended to appropriate villager rice fields into the boundaries. This was responded with a strike by hired villagers because of the fear of violent retaliation from their neighbors/relatives who owned the rice fields. When the mapping was completed, it was clear that parts of the protected forest overlapped with villager cropland plots. Another impact of the protected forest establishment was the stoppage of much needed basic infrastructure. With the protection forest designation, roads connecting Nuha and a neighboring village (Matano) were made inaccessible, for it was now located within the protected forest area. This also deprived the village from accessing much public infrastructure improvement.

The pepper boom in the area represents another crisis. The new commodity boom prompted widespread land conversion across the regency with people from other parts of the province coming to the regency seeking land to grow pepper, and Nuha saw an increasing number of outsiders arriving to convert protected forests for pepper cultivation. In 2018, some villagers found out that a patch of protected forest by the lake had been burned, followed by lines of wooden posts planted to prepare for pepper cultivation, as well as a hut built for the person who would oversee the future grove. The villagers then reported to the village government to confront the encroacher, who responded that the investor was a dignitary at the regency level. He was tasked to clear the land. When pressed further, the encroachers could not show any proof of such claim. The next day, they disappeared. The villagers then learned the encroacher came to the protected area at a neighboring village, Matano, and the villagers there were not immediately aware of their activities. Since then the Nuha villagers became concerned about such activities that can come from any direction targeting the forested areas far from their settlement.

Community based conservation in Nuha is not new. The Nuha villagers are well aware about potential calamities from forest degradation. They know that the slope areas are not to be deforested as it will stimulate landslides. They obey the traditional 'boundaries' between the cropland and what they perceive as forest areas. This tradition is passed down through the generations. As Nuha swidden practices include a six to seven years cycle, they do not clear traditional forests for a new cycle of rotating cultivation. They follow the messages from their ancestors to avoid such actions. Another traditionally protected area is left unexploited to follow the ancestor message to ban tree cutting altogether within the area. They believe, and some people reported magical incidents within the area. The Kaloju trees (Palagium sp) within these protected areas are left untouched and thriving, although the trees can make for good pepper posts. Instead they buy posts for pepper cultivation which cost them Rp 30,000-35,000 a piece (Rp 35,000 equal to USD 2.4). This area also happens to be an important source of water for agricultural activities. They do not learn this rule through verbal or formal education, but by witnessing actions of their parents. From an early age they join their parents to move around practicing swidden agriculture. As one elder recalled, "We live like nomads, from one cropland to another, and come back to the first one after six years. As children we were asked to join [our parents]." In terms of conserving the lake, in the past local people believed that it was bad for them to wash dishes in the lake because that would invite crocodiles and cyclones. Although today this belief is losing weight, people from Nuha still tend to avoid treating the lake as a place to clean dishes or dump garbage. 
It is against this background that the projects by Perkumpulan Wallacea and Unanda came to Nuha. The project activities have stimulated a vision of possible changes to improve the socialecological system (i.e., of potential project outcomes), which is what we turn to next.

\subsection{Catalytic Elements}

\subsubsection{Involvement and commitment of key players}

NGOs (Perkumpulan Wallacea and Burung Indonesia), university (Unanda), villagers' community groups (agroforestry group), as well as government and international donor agencies (Critical Ecosystem Partnership Fund, CEPF) are all involved in different capacities for the CBC in Nuha. The key players of the projects represent organizations from multiple levels. The international donor (CPEF) provided initial and project funding, while the village government later added supplementary funds and supported with their labor. Meanwhile, the CEPF partner in Indonesia (Burung Indonesia) and Unanda delivered their expertise. The local NGO (Perkumpulan Wallacea) runs the facilitation and networking, aside from sharing their skills. Finally, the villagers (and their community-based organization established during the project) offered their local knowledge and labor.

What is important here is the continued involvement of the community members. The Nuha community commitment sustained the initiative beyond the project end date and continued until through the time of research (April 2019), with indications that commitment will remain strong. This may be due to the real and envisioned crises as well as opportunities mentioned above. But it may also have stemmed from the nature of the participation of the villagers and government. The projects run by Perkumpulan Wallacea, for instance, were designed as participatory from the. Participatory mapping and PLUP involved community groups as well as village government along the entire processes, and produced broader awareness of key issues, convening villagers to discuss them, and remaining involved through the policy and budgeting level processes.

Finally, the active participation of the community members may stem from a longstanding collective action tradition in Nuha. There are two types of collective action in Nuha, sicurung-curung and meliuha. Sicurung-curung (litt. 'help each other') is a reciprocal type of collective action carried out in rituals related to life cycle. Meliuha (litt. 'work together'), is working collectively on croplands, mainly practiced on food or subsistence production, including preparing the plot, planting and harvest. A meliuha group normally comprises ten to fourteen people, and it usually takes one or two days working in each of the members' plot, since each group member typically owns a fourth to one hectare of cropland.

\subsubsection{Funding}

Aside from the funding from the international donor agency, the recent change in the national legal structure contributed to the availability of funds for the project from the village. The 2014 Village Law provided authority to the village government to fund village development programs, which are drafted through village deliberations. The Nuha village government was able to fund part of the participatory mapping, PLUP, as well as other activities that emerged as part of the project. At higher levels, the Lake Malili Forum, where Nuha holds membership, advocates for regency funds to continue their work on coordinating multi-stakeholder conservation and development around the lake complex.

The project activities also created new networks originating from the parties involved in them, and in some ways contributed funding for the initiative. For instance, P.T. Vale, the large nickel company of the region had broken their promise to fund the endemic tree nursery, and planting was subsequently carried out by the Nuha agroforestry group. The cost incurred in this activity 
finally got covered by the local government agencies (KPHL [forest management unit] and BLHD [regency environmental agency]) by funds initiated by the project.

\subsubsection{Leadership}

As described by Seixas and Davy (2007) leadership in CBC may be a person or organization that can carry out different tasks simultaneously or in sequence, and takes up a role as innovator, bridgebuilder, communicator, learner, and/or systems thinker. During the initial stage, it is the local implementing organizations that seem to be taking the leadership role. The Perkumpulan Wallacea representative led the projects as a "bridge-builder" by facilitating the process to organize community, building networks, and helping them to envision the desired future. Meanwhile, the Unanda representative led as a "learner" by promoting the importance of learning through participatory survey on endemic trees, and also as a "communicator" by sharing important knowledge of conservation.

As the capacity building elements (see below) also succeeded in providing better knowledge and skills to the community groups involved, an informal community leader also emerged. At this later stage, when the participatory activities were underway and multi-stakeholder meetings and workshops began, this leader become an innovator by supporting the community group to take welltimed risks (for instance, suggesting the group to engage in new contracts with government agency for endemic tree nursery) and served as communicator by compellingly articulating a vision for the future of the village, one with conservation as a strong consideration. The village government, as mentioned above, provided formal legitimation for the projects, but was not involved intensively. At the final stage of the project and at the higher governing scales, such as the Lake Malili Forum that was formed at the regency level, a charismatic and respected leader who is also a high official at the regency level took on the leadership role as "innovator" by taking risks and pulling together different stakeholders in a new direction.

Therefore, the case shows that all types of leadership roles are present and that each stakeholder seems to take up leadership in different phases of the project. The NGO and university took on a key leadership role during the initial stage, while the community members and village government followed up during much of the project's timeline, and finally a regency official fulfilled a crucial role during the final stage of scaling up to regency level. However, scaling up at the regency level is still underway, and a key sign is that the activities within the village continue to progress, with ownership by the villagers themselves, maintaining the $\mathrm{CBC}$ arrangements beyond the life of the project. Beyond individual leadership dimensions, the village government has also adopted PLUP for village planning, which points to key elements of sustainability regarding the CBC initiative (i.e. participatory decision making and sustainable land use).

\subsubsection{Capacity building}

Capacity building may represent the most important catalytic element that propelled and maintained the CBC in Nuha. Unanda began with participatory surveys on the threatened and endemic species and their habitats, and then proceeded to introduce and raise awareness about endemic trees, before providing training to community groups to rehabilitate these endemic trees. Meanwhile, Perkumpulan Wallacea organized the communities to work around sustainable land use and participatory decision making processes. Their main agenda was PLUP, as well as organic farming initiatives such as agroforestry and trigona bee breeding. The Perkumpulan Wallacea trained them to use GPS devices and to import data to computer and create maps that influenced local planning decisions. It is however unclear whether the villagers are now actually able to use these skills or importing, managing and updating data to their computers. Nevertheless, they at least clearly understand their operation, role, and potential. 
Together, Unanda and Perkumpulan Wallacea shared knowledge and skills on mapping, planning, endemic species and habitats, regulation around land use and protected areas, budgeting and planning, nursery and organic farming, as well as on advocacy skills. Aside from the skills and knowledge, these capacity building activities also produced policies, regulations, and important documents (i.e. village land use maps and an MoU between community groups and government agencies). Importantly, these capacity building support resulted in empowering the community group 'leveling the playing field' for higher level advocacy and/or multi-level co-management of natural resources (Sarmiento Barletti and Larson 2019).

After participatory mapping, the traditionally protected areas were formalized through the village deliberation as Community Protection Area (Wilayah Perlindungan Masyarakat). Through the map and PLUP, people in Nuha were able to participate in correcting the overlaps between the protected forest area and their private land plots. They also realized that the village map can become an important tool to avoid future encroachment or unproven claims of land along the village borders. In other words, the participatory mapping can be a tool to anticipate future land conflicts. This function is also spreading to other villages. One of the Nuha community leaders introduced this function when asked to advocate for participatory mapping in another village.

The experience of encroachment of the protected forest and lack of rangers dispatched around the village to monitor the area ${ }^{11}$ also inspired the village government to ask the provincial Forest Management Unit (KPH) to provide them with a formal letter that legalizes them to monitor the forest (i.e. as community ranger). ${ }^{12}$ The villagers said that they need such legal support to confront encroachers who claimed they were sent by local strongmen or high officials. The KPH promised them to provide the letter; however, it was not materialized until the time of the fieldwork. This was the case even when Nuha received prizes and certificates of appreciation by several institutions for success in maintaining the forest. Nevertheless, since the last confrontation with encroachers, Nuha has not experienced any new attempts of forest encroachment for pepper cultivation.

PLUP also opened up a new opportunity for village infrastructure improvements. During PLUP they allocated new plots for settlements, and together with public facilities such as schools, playgrounds, and additional roads, helped to ensure each housing plot had access to the road. They also planned to open up new rice fields. This plan was made by maintaining the traditionally protected area and showed how local knowledge can function during participatory planning. For instance, the area planned as a rice field is well known by villagers as relatively flat (easier and less costly to prepare and does not entail future landslides) and has multiple water sources (including several streams). The allocation of the housing plots in the actual location was attended by most of the villagers. The plan was partly a response to the new map produced through participatory mapping. The map provide a bird eye view of the village and added a new realization of the villagers' spatial consciousness, where they can actually see spatially how tiny their settlement area was relative to the other usages of the village area (such as protected forest): the size of the entire village is around 60,000 ha, the current settlement area is 25.2 ha, 'miscellaneous usage area' (APL, including settlement, rice field, cropland, and public facilities) is 112 ha, and protected forest is around 10,200 ha. Another reason for the new settlement plan was the anticipated population growth.

\footnotetext{
11 One villager said: "it should have been good if they come to patrol three times a year, but it's not the case."

${ }^{12}$ Challenges in $\mathrm{KPH}$, an institutional mechanism used in Indonesia for coordinating the management of competing sectors in forest landscape, and balancing the interest of different actors, discussed in Riggs et al. (2018).
} 


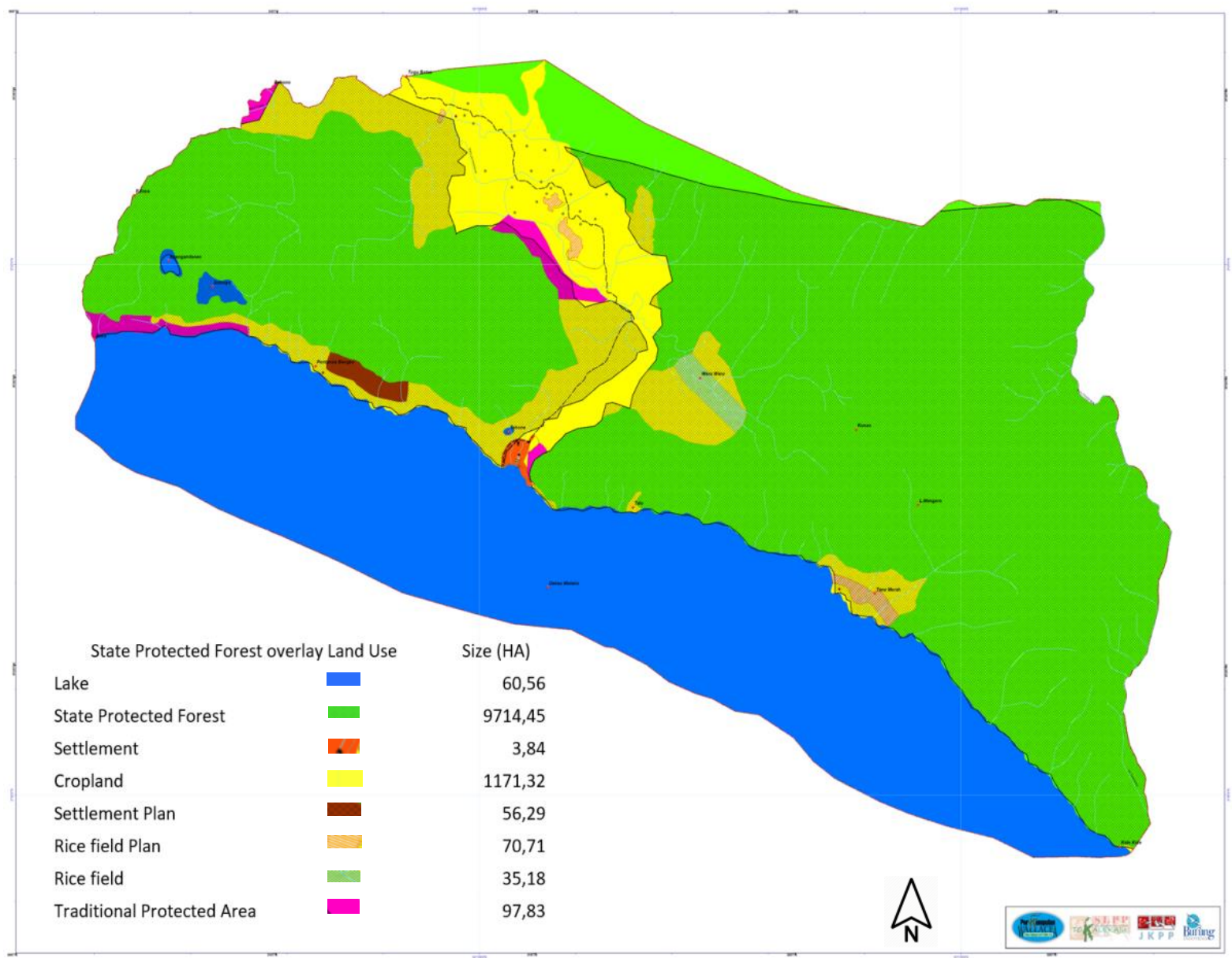

Figure 1. Map of Nuha land use overlaid by the State Protected Forest Area as a Result of the local PLUP initiative.

New insights on conservation formed as a result of intensive interactions with the NGOs. A village leader expressed his aspiration that the uniqueness of Nuha should stem from their forest. In his own words:

"Nuha is not a money printer because here we don't have a big source of money like Soroako

(i.e. nickel mining). I am thinking about how the forest can be kept intact as the main source of life. Here in Nuha nobody [villagers] works as a civil servant, meaning that all of us are farmers. We are all tied to the land, so the forest should be conserved."

In fact, Nuha is hailed as the "last primary forest" (Rimba Terakhir) by some environmental organizations in regional advocacy groups for forest conservation. Indeed, another elder said, "Today, as illegal logging had stopped for dozens of years, the forest cover has increased. If we go into the forest now, we can get lost."

\subsubsection{Partnership}

The $\mathrm{CBC}$ in Nuha benefitted from multiple organizations from different governing levels. The project involved international donors and a national environmental organization, as well as a local NGO and university. As mentioned, while Wallacea and Unanda were the partners on the ground that invited Nuha to be part of the projects, the international donor and national organization were the one initiated the project. When the actual work began, the village government joined in and supported with budget and planning; which also mean that the Village Law, via the village 
government, could deliver support through a national legal structure more supportive of local autonomy.

At a later stage, the establishment of the Lake Malili Forum provided additional backing that broadened the reach of the initiative at the regency level. The Forum provided the Nuha community groups (i.e. agroforestry group, village level lake forum, and village assembly) with more knowledge and information, and networks, yet this remains lacking on the bargaining position at the regency level (see Sirimorok and Rusdianto, this issue).

\subsubsection{Economic incentives and alternative livelihood options}

The economic incentive is by far the weakest element seen in the project. Some villagers think that the nursing and planting of endemic trees might bring direct financial benefit to the next generations if they can receive contracts to provide these services (nursing and planting). On this logic, they refer to the pepper nursery they also prepare for the government or through private contracts in the last couple of years. Indeed, during the project period the endemic tree nursery and planting were carried out in the village by the agroforestry group with some financial compensation, yet it is still questionable whether this enterprise will be sustainable. Others think of this effort in environmental and social terms: that Nuha will be the first village in the area to have a digital map created from a participatory mapping initiative, and known for their endemic trees, which most likely attract further research and future project support. Therefore, if they begin to plant the trees around the cropland areas, researchers will not have to go far into the forest to find them. Other economic activities facilitated by Perkumpulan Wallacea, such as the bee nursery, introduction of other environmentally friendly crops, and composting, seem to have been short lived as they are still unattractive propositions financially and lack market demand.

The incentives gained from the $\mathrm{CBC}$ represented an important factor that helped to maintain community commitment, and this was often interpreted in economic terms, as also described in Seixas and Davy's research (2007). However, equity and empowerment is frequently seen as significant incentives since the 'community' involved in $\mathrm{CBC}$ also came from the more marginalized part of the society or groups of the community (Berkes, 2004), and in this case benefitted from the opportunity to make strong claims to land. PLUP resulted in infrastructure improvement plans realized in the ability to also make strong claims to budgetary support relative to surrounding villages. They mentioned how the plan will result in a new housing zone from the protected area that they felt was mistakenly delineated in the past. This will enable the government to rebuild and reactivate the abandoned road. This will also lift a longstanding marginalization effect experienced by Nuha and improves access to their neighbors and further to the regency capital. In addition, an informant stated how the forests that Nuha protect help supply water to the lakes, and how the water volume in the lake is crucial for running PT. Vale's hydropower plants, without which the entire company operation would not be able to function, depriving the whole regency from electricity. Ironically however, the village remains without access to electricity. Referring to village development one local informant said: "Indonesia has been independent for [more than] 70 years, but we still do not [...] have any electricity."13

\section{Discussion and Conclusion}

In this paper, we examined to what extent one framework on evaluating $\mathrm{CBC}$ initiatives was confirmed, present, or manifested at a site in Nuha, Sulawesi. Examining the case through the framing of triggering moments and catalytic elements provided a useful lens for analyzing programmatic $\mathrm{CBC}$ initiatives.

${ }^{13}$ They also know that most houses in Soroako do not have to pay an electric bill as they are covered by the company. 
The case of $\mathrm{CBC}$ in Nuha presents how crises related to land rights and commodity booms combined to deprive local people of land and public facilities. A sense of crisis from enclosure of their protected forests also shaped their interests. These policies and events threatened their dominant livelihoods. These triggers formed a strong motivation for the community members and village government to respond positively to the arrival of a CBC project brought by a local organization and university, supported by international donor funding. The project provided, activated, and produced new catalytic elements: new networks and partnerships, funding, capacity building, leadership, and to a lesser degree, incentives. We presented these triggering moments and catalytic elements, relative to the dimensions that significantly contributed to CBC success in Nuha.

There are some notes about this successful CBC initiative in Nuha that require further scrutiny however. Seixas and Davy (2007) pointed out that one hypothesis to be tested in further research is that when some of the key elements disappear, continued success becomes difficult. In this case, after the projects ended some of these catalytic elements were fleeting, or partly disappeared, such as the facilitation of new livelihood projects on Trigona Bees. Overall funding from the projects dissolved and economic activities related to the projects were unsustainable incentives. It remains to be seen whether the non-economic incentives (equity and empowerment) and strong leaderships - partly shaped by the capacity building activities during the projects - can maintain the CBC in Nuha.

Furthermore, the involvement and partnership with outside key players after the end of the project will continue to diminish without follow up projects. The NGO, university, and donor finished their project in Nuha, and the CBC in Nuha must continue through their own self-organizing, and a rather weak network with the regency government agencies that were attempted for establishment during the projects. This deficiency of the crucial regency level may create negative consequences on the initiative in the future. This is so for two reasons. First, as the initiative was project based, local organizations might not follow up afterwards. The Lake Malili Forum was designed to provide continued political and financial support to the initiative after the project ended, but this is far from automatic. Second, some related planned activities or policies in Nuha still require support from the Forum, without which the plans might have to wait much longer, if realized at all. This will weaken the commitment of the villagers on the initiative. For instance, the area planned for the new settlement and rice field currently fall within the formally delineated protected forest area. The plan has been adapted to the village formal development plan, and they are advocating the area to be released: multiple meetings with the local $\mathrm{KPH}$ have been done for this purpose. The villagers mentioned that they are hopeful as the head of the regency (bupati) had promised to release land to local communities at an amount as much as 70,000 ha during his campaign for office. Nevertheless, a stronger and sustained political push is still needed because such release of lands also involves buy-in from national agencies. It thus remains to be seen whether the fleeting partnership will weaken community commitment on the CBC initiative in Nuha.

Therefore, the detailed examination of the Nuha case through the lens of triggering moments and catalytic elements shows that some considerations need to be addressed about the current framework. First, although the catalytic elements can provide indicators to be assessed immediately before and during a project or initiative, it lacks the explanatory processes, dynamics, and traditions that put the elements in place to support the process. In other words, we still need to identify underlying factors that contribute to success or failure of a CBC project, which we have endeavored to do by providing context of the study site. Some of these are no doubt directly related to the triggering moments such as the Village Law, which provided broader authority and autonomy to the village government to produce budgets and development planning, as well as the traditional rules to protect certain parts of the forest. Nevertheless, such frameworks are still unable to closely assess the pre-existing determining factors of land and natural resource dimensions that will lead to those successes in the first place. For these reasons the classical literature on the commons and power relations of political ecology still provide much value. 
Further research is thus needed as to why the network and partnership at the regency level and dimensions relating to the neighboring mining corporation PT Vale is lacking. Here, the notion of power relations in multi-stakeholder land use management is critical (Sarmiento Barletti and Larson, 2019). The $C B C$ as a partnership of multiple actors requires that the initiative be aware of power relations both within the community and between the community and the other more powerful actors across different levels (Berkes, 2004). Hence, the link between local phenomena to the wider systems needs to be examined in a 'chain of explanation' (Blaikie, 1999).

Second, another underlying factor prone to neglect by the framework is the enduring collective action tradition in Nuha. This tradition may have contributed strongly to the ease of self-organizing and/or mobilization during the $\mathrm{CBC}$ projects. Indeed, this tradition may have also underpinned the sustainability of the CBC project in Nuha. However, such factors were difficult to capture in our application of the $\mathrm{CBC}$ framework, and thus more research is required to delve into the extent that these underlying traditional and community relations helped Nuha villagers manage a successful CBC project. In this regard, studies under critical institutional approach (Cleaver and de Koening, 2015; Saunders, 2015) provide a more nuanced framework to explore the function of informal institutions that are based on local norms and values in a CBC initiative.

Third, the use of the terms 'moments' in 'trigger moments' imply that the approach emphasizes short term phenomena instead of longer term processes and dynamics. Crises experienced by the villagers were in fact part of enduring processes and dynamics, namely related to the passive land disputes with state forest authorities, which began almost two decades ago when the mapping for the establishment of protected forests took over some of their plots. Meanwhile, the pepper boom is another wave of commodity booms reshaping rural communities in Sulawesi (Li, 2014). But before pepper, then there was agarwood, cocoa, and kalapi timber. Their longstanding dual economy tradition allowed this to take place, but which prioritized some elements of land use over others.

Finally, the notion of actual and envisioned crises that open the opportunity to community selforganizing for $\mathrm{CBC}$ are prone to drive attention away from what the community already has, such as the collective action tradition embedded in their everyday life. All of these crises also reveal the importance of considering processes that take place at a wider scale, namely, national government policy change and market dynamics as part of the driver of the crises (Cleaver and de Koening, 2015), and the CBC as a "nested enterprise" in a larger governance system (Ostrom, 1990).

The approach, hence, is lacking the question of the underlying factors that made the 'catalytic elements' possible before the project started, and the broader processes and dynamics that caused the 'triggering moments' to appear. By exploring these longstanding traditions and broader dynamics and processes, we may be able to identify more factors that underpin or produce the catalytic elements.

\section{Acknowledgments}

The research was supported by the Critical Ecosystem Partnership Fund (CEPF) through Burung Indonesia. However, this paper solely represents the researchers view, and not necessarily those of CEPF. The writing process was assisted by Forest and Society, and the review and feedback has been very valuable in developing the ideas for this article.

\section{Conflicts of interest}

The authors declare no conflict of interest.

\section{References}

Adams, W.A. (2003) 'Nature and the colonial mind'. In Adams W.A \& Mulligan Martin (eds) Decolonizing nature: Strategies for conservation in postcolonial era, p. 16-50

Baggio, J. A., Barnett, A. J., Perez-Ibarra, I., Brady, U., Ratajczyk, E., Rollins, N., ... Janssen, M. A. (2016). Explaining success and failure in the commons: the configural nature of Ostrom's 
institutional design principles. International Journal of the Commons, 10(2), 417-439. doi: http://doi.org/10.18352/ijc.634

Berkes, F. (2004). Rethinking community-based conservation. Conservation biology, 18(3), 621-630. doi: https://doi.org/10.1111/j.1523-1739.2004.00077.x

Blaikie, P. (1999). A review of political ecology. Zeitschrift für Wirtschaftsgeographie, 43(1), 131-147. doi: https://doi.org/10.1515/zfw.1999.0009

Cleaver, F. D., \& de Koning, J. (2015). Furthering critical institutionalism. International Journal of the Commons, 9(1), 1-18. doi: http://doi.org/10.18352/ijc.605

Cox, M., Arnold, G., \& Tomás, S. (2010). A Review of Design Principles for Community-based Natural Resource Management. Ecology and Society, 15(4). Retrieved April 22, 2020, from www.jstor.org/stable/26268233

Dove, M. (2012). The Banana Tree at The Gate: A History of Marginal Peoples and Global Markets in Borneo. Singapore: NUS Press.

Hall, D., Hirsch, P., \& Li, T. M. (2011). Introduction to powers of exclusion: land dilemmas in Southeast Asia.

Horwich, R. H., \& Lyon, J. (2007). Community conservation: practitioners' answer to critics. Oryx, 41(3), 376-385. doi: https://doi.org/10.1017/S0030605307001010

Lemos, M. C., \& Agrawal, A. (2006). Environmental governance. Annu. Rev. Environ. Resour., 31, 297325. doi: https://doi.org/10.1146/annurev.energy.31.042605.135621

Li, T. M. (2014). Land's end: capitalist relations on an indigenous frontier. Duke University Press.

Ostrom, E. (1990). Governing the Commons: The Evolution of Institutions for Collective Action. Cambridge: Cambridge University.

Pearson, R. G. (2016). Reasons to conserve nature. Trends in Ecology \& Evolution, 31(5), 366-371. doi: https://doi.org/10.1016/j.tree.2016.02.005

Rahayu, S., Laraswati, D., Pratama, A. A., Permadi, D. B., Sahide, M. A., \& Maryudi, A. (2019). Research trend: Hidden diamonds-The values and risks of online repository documents for forest policy and governance analysis. Forest policy and economics, 100, 254-257. doi: https://doi.org/10.1016/j.forpol.2019.01.009

Ribot, J. C., \& Peluso, N. L. (2003). A theory of access. Rural sociology, 68(2), 153-181. doi: https://doi.org/10.1111/j.1549-0831.2003.tb00133.x

Riggs, R. A., Langston, J. D., Margules, C., Boedhihartono, A. K., Lim, H. S., Sari, D. A., ... \& Sayer, J. (2018). Governance challenges in an Eastern Indonesian forest landscape. Sustainability, 10(1), 169. doi: https://doi.org/10.3390/su10010169

Sandbrook, C. (2015). What is conservation?. Oryx 49(9), 565-566. doi: https://doi.org/10.1017/\$0030605315000952

Sarmiento Barletti, J.P., and Larson A.M. (2019). The role of multi-stakeholder forums in subnational jurisdiction. Occasional Paper 194. CIFOR

Saunders, F. P. (2014). The promise of common pool resource theory and the reality of commons projects. International Journal of the Commons, 8(2), 636-656. doi: http://doi.org/10.18352/ijc.477

Seixas, C. S., \& Davy, B. (2007). Self-Organization in Integrated Conservation and Development Initiatives. International Journal of the Commons, 2(1), 99-125. doi: http://doi.org/10.18352/ijc.24

Sirimorok, N., \& Rusdianto, E. (2020). The Importance of Being Political: Emergence of a Multistakeholder Forum at the Lake Malili Complex, South Sulawesi. Forest and Society, 4(1), 98-114. doi:http://dx.doi.org/10.24259/fs.v4i1.7442 